Egyptian Journal of Aquatic Biology \& Fisheries

Zoology Department, Faculty of Science,

Ain Shams University, Cairo, Egypt.

ISSN $1110-6131$

Vol. 23(1): 299 -304 (2019)

www.ejabf.journals.ekb.eg

\title{
Bacterial diversity and distribution in Soft Corals and Sponges in the Red Sea
}

\section{A. M. Sallam ${ }^{1}$, M. El Hriri ${ }^{2}$, M. A. Mahmoud ${ }^{3}$ and J. El-Jakee ${ }^{2}$}

1- National Organization for Drug Control and Research, Cairo, Egypt.

2- Department of Microbiology, Faculty of Veterinary Medicine, Cairo University.

3 -National Institute of Oceanography and Fisheries, Red Sea Branch, Egypt.

\section{ARTICLE INFO}

Article History:

Received: Jan.23, 2019

Accepted:Feb. 26, 2019

Online: March 2019

\section{Keywords:}

Bacteria

Diversity

Soft Corals

Sponges

Red Sea

\section{ABSTRACT}

The Red Sea has high biodiversity, with at least 266 coral and sponge species. The coral/Sponge holobiont is comprised of the coral/sponge animal and its associated microorganisms consisting of bacteria, archaea, fungi and viruses. It has been hypothesized that this interaction plays a role in coral/ sponge defense. This study aims to study the bio-diversity of some collected types of sponge and soft coral from Red Sea and to isolate associated bacteria from them. The result includes five types of sponges; Ircinia strobilina, Callyspongia viridis, Suberea spp., Spongia officinalis and Biemna ehrenbergi and five types of soft corals; Heteroxenia fuscescens, Didemnum moseleyi, Lobophytum pauciflorum, Sarcophyton trocheliophorum and Sinularia spp. Twenty two bacterial isolates were isolated from the sponges with $41 \%$ and thirty two bacterial isolates were isolated from soft coral samples with $59 \%$ collected from different Red Sea areas.

\section{INTRODUCTION}

Coral reefs are well developed along Red Sea which has a coast extend to 2270 $\mathrm{Km}$ (Kotb et al., 2008). It contains biologically diverse sponges and corals and considered to be among the most diverse in the world species (Loya, 1972). These corals and sponges show contrasts in their biology and environmental attributes (Sheppard et al., 1992). They are considered economically valuable, providing shelter, food and breeding sites for plants and animals living in oceans (Rinkevich, 2005). Sponges and coral reefs are considered to be natural ecosystem and provide an excellent habitat for marine organisms due to their structure and high retention of nutrients (Stoeckl et al., 2014). Bacteria and other microorganisms are ubiquitous in the marine environment are taxonomically diverse and biologically active (Rheinheimer, 1992). Marine organisms such as corals and sponges are mostly colonized by bacteria and the surface of living corals is covered by mucus which is colonized by bacteria, allowing for the establishment of diverse bacterial community, some of these bacteria can be pathogenic and some of them can be beneficial (Ritchie et al., 2017). So this study aims to study the bio-diversity of some sponge and soft coral collected from Red Sea. 


\section{MATERIALS AND METHODS}

\section{Soft coral/Sponge collection and cultivation condition}

From three different areas in Red Sea, Egypt, in depth of $\pm 5-8 \mathrm{~m}$, sponge and soft corals sampled were collected and transferred into a sterilized plastic bag under the water itself and stored in the ice box and transferred to the laboratory for identification and isolation of the associated bacteria.

\section{Isolation of sponge and soft coral associated bacteria (Chen et al., 2012)}

Sponge and soft corals samples were washed with autoclaved filtered sea water. Sponges and soft corals were cut into small pieces and were homogenized by grinding using sterile mortar and sterile sea water.

Table 1: biochemical test used for bacterial identification using VITEK 2.

\begin{tabular}{|c|c|}
\hline Gram Negative tests & Gram Positive testes \\
\hline Ala-Phe-Pro-ARYLAMIDASE & D-AMYGDALIN \\
\hline ADONITOL & PHOSPHATIDYLINOSITOL PHOSPHOLIPASE C \\
\hline L-Pyrrolydonyl-ARYLAMIDASE & D-XYLOSE \\
\hline L-ARABITOL & ARGININE DIHYDROLASE 1 \\
\hline D-CELLOBIOSE & BETA-GALACTOSIDASE \\
\hline BETA-GALACTOSIDASE & ALPHA-GLUCOSIDASE \\
\hline H2S PRODUCTION & Ala-Phe-Pro ARYLAMIDASE \\
\hline BETA-N-ACETYL-GLUCOSAMINIDASE & CYCLODEXTRIN \\
\hline Glutamyl Arylamidase pNA & L-Aspartate ARYLAMIDASE \\
\hline D-GLUCOSE & BETA GALACTOPYRANOSIDASE \\
\hline GAMMA-GLUTAMYL-TRANSFERASE & ALPHA-MANNOSIDASE \\
\hline FERMENTATION/ GLUCOSE & PHOSPHATASE \\
\hline BETA-GLUCOSIDASE & Leucine ARYLAMIDASE \\
\hline D-MALTOSE & L-Proline ARYLAMIDASE \\
\hline D-MANNITOL & BETA GLUCURONIDASE \\
\hline D-MANNOSE & ALPHA-GALACTOSIDASE \\
\hline BETA-XYLOSIDASE & L-Pyrrolydonyl-ARYLAMIDASE \\
\hline BETA-Alanine arylamidase & BETA-GLUCURONIDASE \\
\hline L-Proline ARYLAMIDASE & Alanine ARYLAMIDASE \\
\hline LIPASE & Tyrosine ARYLAMIDASE \\
\hline PALATINOSE & D-SORBITOL \\
\hline Tyrosine ARYLAMIDASE & UREASE \\
\hline UREASE URE & POLYMIXIN B RESISTANCE \\
\hline D-SORBITOL & D-GALACTOSE \\
\hline SACCHAROSE/SUCROSE & D-RIBOSE \\
\hline D-TAGATOSE & L-LACTATE alkalinization \\
\hline D-TREHALOSE & LACTOSE \\
\hline CITRATE (SODIUM) & N-ACETYL-D-GLUCOSAMINE \\
\hline MALONATE & D-MALTOSE \\
\hline 5-KETO-D-GLUCONATE & BACITRACIN RESISTANCE \\
\hline L-LACTATE alkalinization & NOVOBIOCIN RESISTANCE NOVO \\
\hline ALPHA-GLUCOSIDASE & GROWTH IN $6.5 \% \mathrm{NaCl}$ \\
\hline SUCCINATE alkalinization & D-MANNITOL \\
\hline Beta-N-ACETYL-GALACTOSAMINIDASE & D-MANNOSE \\
\hline ALPHA-GALACTOSIDASE & METHYL-B-D-GLUCOPYRANOSIDE \\
\hline PHOSPHATASE & PULLULAN PUL \\
\hline Glycine ARYLAMIDASE & D-RAFFINOSE \\
\hline ORNITHINE DECARBOXYLASE & O/129 RESISTANCE (comp.vibrio.) \\
\hline LYSINE DECARBOXYLASE & SALICIN \\
\hline DECARBOXYLASE BASE & SACCHAROSE/SUCROSE \\
\hline L-HISTIDINE assimilation & D-TREHALOSE \\
\hline COUMARATE CMT & ARGININE DIHYDROLASE 2 \\
\hline BETA-GLUCURONIDASE & OPTOCHIN RESISTANCE \\
\hline \multicolumn{2}{|l|}{ O/129 RESISTANCE (comp.vibrio.) } \\
\hline \multicolumn{2}{|l|}{ Glu-Gly-Arg-ARYLAMIDASE } \\
\hline \multicolumn{2}{|l|}{ L-MALATE assimilation } \\
\hline \multicolumn{2}{|l|}{ ELLMAN } \\
\hline L-LACTATE & \\
\hline
\end{tabular}

Serial dilution for the soft coral and sponge homogenates to $10^{-6}$, then $0.1 \mathrm{ml}$ were streaked on six general bacterial media (Marine Agar (Oxoid), R2A Agar (Difco Lab), Starch casein Agar (HIMEDIA), ISP2 Medium (Difco Lab), Actinomycetes Medium (HIMEDIA) and M1 Agar (Oxoid) and incubated at $25^{\circ} \mathrm{C}$ for 7 days, starting from the third day to the seventh day colonies with different characters were picked up and re-streaked again to obtain pure cultures (Wilson et al., 2010). 
Identification of associated bacteria (Moehario et al., 2019).

Identification of bacterial isolates after Gram staining was performed by using VITEK 2 (bioMerieux). It is an automated full system used for bacterial identification. It works by evaluating each biochemical reaction present in microbial identification cards by using optical signals. Suspension with unknown bacteria is inoculated and then incubated with identification cards.

\section{RESULTS}

\section{Collection of Soft oral and sponge:}

Sponge samples:

Eight samples collected from 5 sponges species were collected from red sea as shown in Table 2.

Table 2: Sponge classification

\begin{tabular}{lll}
\hline Name & Type & Number of Samples \\
\hline Ircinia strobilina & Sponge & 1 \\
Callyspongia viridis & Sponge & 1 \\
Suberea spp. & Sponge & 2 \\
Spongia officinalis & Sponge & 2 \\
Biemna ehrenbergi & Sponge & 2 \\
Total & & 8 \\
\hline
\end{tabular}

\section{Soft coral Isolation}

Twelve samples collected from 5 soft corals species were collected and as shown in Table 3.

Table 3: Soft corals classification

\begin{tabular}{lll}
\hline Name & Type & Number of samples \\
\hline Heteroxenia fuscescens & Soft Coral & 2 \\
Didemnum moseleyi & Soft Coral & 2 \\
Lobophytum pauciflorum & Soft Coral & 4 \\
Sarcophyton trocheliophorum & Soft Coral & 3 \\
Sinularia spp. & Soft Coral & 1 \\
Total & & 12 \\
\hline
\end{tabular}

Isolation of Soft coral and sponge associated bacteria

Soft Coral associated bacteria

Thirty two bacterial isolates were isolated and identified from soft coral samples as identified in Table 4

Table 4: Bacterial isolates from soft corals

\begin{tabular}{|c|c|c|c|}
\hline Soft Coral species & $\begin{array}{c}\text { Number of Soft } \\
\text { coral samples }\end{array}$ & Bacterial species & No. of Isolates \\
\hline \multirow[t]{3}{*}{ Didemnum Moseleyi } & 2 & Aerococcus viridans & 1 \\
\hline & & Alloiococcus spp & 3 \\
\hline & & Staphylococcus hominis & 1 \\
\hline \multirow[t]{2}{*}{ Heteroxenia Fuscescens } & 2 & Vibrio spp. & 2 \\
\hline & & Helcococcus kunzii & 3 \\
\hline \multirow[t]{5}{*}{ Lobophytum Pauciflorum } & 4 & Vibrio spp. & 1 \\
\hline & & Staphylococcus epidermidis & 5 \\
\hline & & Aerococcus viridans & 3 \\
\hline & & Staphylococcus gallinarum & 1 \\
\hline & & Staphylococcus saprophyticus & 3 \\
\hline \multirow[t]{3}{*}{ Sarcophyton Trocheliophorum } & 3 & Enterococcus faecalis & 2 \\
\hline & & Granulicatella Elegans & 2 \\
\hline & & Staphylococcus vitulinus & 2 \\
\hline \multirow[t]{2}{*}{ Sinularia spp. } & 1 & Lactococcus garvieae & 2 \\
\hline & & Arthrobacter creatinolyticus & 1 \\
\hline Total & 12 & & 32 \\
\hline $\begin{array}{l}\text { Percent from the total } 54 \\
\text { isolates }\end{array}$ & & & $59 \%$ \\
\hline
\end{tabular}




\section{Sponge associated bacteria}

Twenty two bacterial isolates were isolated and identified from Soft Coral samples as identified in Table 5

Table 5: bacterial isolates from Sponges.

\begin{tabular}{|c|c|c|c|}
\hline Sponge species & $\begin{array}{l}\text { Number of } \\
\text { sponge samples }\end{array}$ & Bacterial species & No. of Isolates \\
\hline \multirow[t]{2}{*}{ Biemna ehrenbergi } & 2 & Kocuria rosea & 5 \\
\hline & & Kocuria kristinae & 2 \\
\hline Callyspongia viridis & 1 & Kocuria rosea & 4 \\
\hline \multirow[t]{3}{*}{ Spongia officinalis } & 2 & Bacillus pumilus & 2 \\
\hline & & Staphylococcus cohnii & 1 \\
\hline & & Staphylococcus xylosus & 2 \\
\hline Suberea spp. & 2 & Kocuria rosea & 3 \\
\hline Ircinia strobilina & 1 & Kocuria kristinae & 3 \\
\hline Total & 8 & & 22 \\
\hline $\begin{array}{l}\text { Percent from the total } \\
54 \text { isolates }\end{array}$ & & & $41 \%$ \\
\hline
\end{tabular}

\section{DISCUSSION}

Marine environment is considered one of the most diverse environments (Choudhary et al., 2018). The Red Sea is one of these global hotspots for biodiversity contain numerous types of coral and sponges (DiBattista et al., 2016). This study was intended to show the bio diversity for the Marine Macro and Microorganism. Soft corals were classified as; Heteroxenia fuscescens, didemnum moseleyi, Lobophytum pauciflorum, Sarcophyton trocheliophorum and Sinularia spp. which was reported by Ibrahim et al. (2014), Afifi et al. (2016), Hassan et al. (2016), Tarek et al. (2016) and Zubair et al. (2016), . Sponges were classified to: Ircinia strobilina, Callyspongia viridis, Suberea spp, Spongia officinalis and Biemna ehrenbergi, this was reported by Ilan et al. (2004), El-Ganainy et al. (2005), Mohamed et al. (2014) and Shaala and Almohammadi (2017) (2014). In this study bacterial isolated had been isolated from soft coral and sponges as following, Aerococcus viridans, Alloiococcus spp., Enterococcus faecalis, Vibrio spp., Granulicatella elegans, Helcococcus kunzii, Kocuria kristinae, Kocuria rosea, Lactococcus garvieae, Bacillus pumilus, Arthrobacter creatinolyticus, Staphylococcus cohnii, Staphylococcus lentus, Staphylococcus xylosus Staphylococcus epidermidis, Staphylococcus hominis, Staphylococcus saprophyticus and Staphylococcus vitulinus. Generally bacterial isolates from Soft coral was thirty two isolated with $59 \%$ which was higher than sponge which was twenty two isolates with $41 \%$.

That was hypothesized to that sponge is more aggressive than soft corals which make corals develop defense mechanism by having more types of bacteria to grow (Aerts and Rob, 1997).

\section{CONFLICT OF INTEREST}

The present study was performed in absence of any conflict of interest.

\section{REFERENCES}

Aerts, L. A. M. and Rob, V. S. (1997). Quantification of sponge/coral interactions in physically stressed reef community, NE Colombia. Marine Ecology-progress Series - MAR ECOL-PROGR SER., 148: 125-134. 
Afifi, R.; Abdel-Nabi, I. M. and El-Shaikh, K. (2016). Antibacterial activity from soft corals of the Red Sea, Saudi Arabia. J Taibah Univ Sci., 10(6): 887-95.

Chen, Y. H.; Kuo, J.; Sung, P.J.; Chang, Y. C., Lu, M.C.; Wong, T. Y.; Liu, J. K.; Weng, C. F.; Twan, W. H. and Kuo, F. W. (2012). Isolation of marine bacteria with antimicrobial activities from cultured and field-collected soft corals. World Journal of Microbiology and Biotechnology., 28(12): 3269-3279.

Choudhary, A.; Rai, D.; Cotter, P. and Dobson A. (2018). Marine antimicrobials for the food industry. Tresearch, (13): 2.

DiBattista, J. D.; Roberts, M. B. and Bouwmeester, J. (2016). A review of contemporary patterns of endemism for shallow water reef fauna in the Red Sea. J Biogeogr., 43: 423-439.

El-Ganainy, A.; Yassien, M. and Ibrahim, E. A. (2005). Bottom trawl discards in the Gulf of Suez, Egypt. Egyptian J. Aquat. Res., 31.

Hassan, M. H. A.; Rabab, M.; Mona, H.; Tarek, M.; El-Gendy, O. A. and Sleim M. A. (2016). Biological and Chemical Investigation of the Soft Coral Lobophytum pauciflorum Collected from the Egyptian Red Sea. International Journal of Pharmacognosy and Phytochemical Research., 8: 906-911.

Ibrahim, S. R.; Mohamed, G. A.; Shaala, L. A.; Youssef, D. T. and Gab-Alla, A. A. (2014). Didemnacerides A and B: Two new glycerides from Red sea ascidian Didemnum species. Natural Prod. Res., 28, 1591-1597.

Ilan, M.; Gugel, J. and van Soest, R. (2004). Taxonomy, reproduction and ecology of new and known Red Sea sponges. Sarsia., 89: 388-410.

Kotb, M. M. A.; Hanafy, M. H.; Rirache, H.; Matsumara, S.; Al-Sofyani, A. A.; Ahmed, A. G.; Bawazir, G. and Al-Horani, F. (2008). Status of coral reefs in the Red Sea and Gulf of Aden Region. In: Status of Coral Reefs of the World. 2008, 67-78.

Loya, Y. (1972). Community structure and species diver- sity of hermatypic corals at Eilat, Red Sea. Marine Biology, 13: 100-123.

Moehario, H.; Boestami, P.; Edbert, D.; Enty, T. and Robertus, T. (2019). Automation for the identification of Pseudomonas aeruginosa: Comparison of TDR-300B, VITEK®2, and VITEK®-MS. Bioraxi. 10, 1101.

Mohamed, G. A.; Ibrahim, S. R. M.; Badr, J. M. and Youssef, D. T. A. (2014). Didemnaketals D and E, bioactive terpenoids from a Red Sea ascidian Didemnum species. Tetrahedron., 70: 35- 40.

Rheinheimer, G. (1992). Aquatic Microbiology, John Wiley, New York. 3.

Rinkevich, B. (2005). What do we know about Eilat (Red Sea) reef degradation? A critical examination of the pub- lished literature. Journal of Experimental Marine Biology and Ecology., 327: 183-200.

Ritchie, K. B.; Schwarz, M; Mueller, J.; Lapacek, V. A.; Merselis, D.; Walsh, C. J. and Luer, C. A. (2017). Survey of Antibiotic-producing Bacteria Associated with the Epidermal Mucus Layers of Rays and Skates. Frontiers in Microbiology, 81050.

Shaala, L.A. and Almohammadi, A. (2017). Biologically active compounds from the red sea sponge Suberea sp. Pak. J. Pharm. Sci., 30(6): 2389-2392.

Sheppard, C.; Price, A. and Roberts, C. (1992). Marine ecology of the Arabian region: patterns and processes in extreme tropical environments. Academic Press, London.

Stoeckl, N.; Farr, M.; Larson, S.; Adams, V.M.; Kubiszewski, I.; Esparon, M. and Costanza, R. (2014). A new approach to the problem of overlapping values: A case study in Australia's Great Barrier Reef', Ecosystem Services. 10, 61-78. 
Tarek, M.; Ali, A. A.; El Komi, M.; El Hadi, M. and Fayez, S. (2016). Growth Rate Assessment of Alcyonacean Sarcophyton glaucum Northern Hurghada, Red Sea, Egypt. Natural Resources, 7: 384-398.

Wilson, G. S.; Raftos, D. A.; Corrigan, S. L. and Nair, S. V. (2010). Diversity and antimicrobial activities of surface-attached marine bacteria from Sydney. Microbiol. Res., 165(4). 300-311.

Zubair, M; Alarif, W.; Al-Footy, K.; Mohamed, P.H.; Ali, M. and Basaif, S. (2016). New antimicrobial biscembrane hydrocarbon and cembranoid diterpenes from the soft coral Sarcophyton trocheliophorum. Turk. J. Chem., 40(3): 385-92. 